\title{
KINERJA SEKTOR PERTANIAN DI PROVINSI JAWA TIMUR PADA MASA PANDEMI COVID-19
}

\section{(Agricultural Sector Performance In East Java Province During The Covid-19 Pandemic)}

Ines Paramithasari, Sri Widayanti, Nuriah Yuliati, Prasmita Dian Wijayati

Program Studi Agribisnis, Fakultas Pertanian, Universitas Pembangunan Nasional "Veteran" Jawa Timur

Jl. Rungkut Madya No.1, Gn. Anyar, Kec. Gn. Anyar, Kota Surabaya, Jawa Timur 60294 Penulis koresponden : sriwidayanti@upnjatim.ac.id

Article Submitted : 16-08-2021

Article Accepted : 24-09-2021

\begin{abstract}
The study was intended to analyze the position of the agricultural sector in the East Java Province of the covid-19 pandemic by determining the position of the agricultural sector at the time before the covid-19 pandemic and the covid-19 pandemic and identifying the factors that determined how the agriculture sector was performing. The collection of data on this study is a secondary data obtained from the Statistical Center and the Indonesian Bank. The method of data analysis used is the Location Quotient analysis (LQ) and the Shift Share. This examination proposes that the situation of the agricultural sector at the time before the covid-19 pandemic was a non-base sector with an LQ value of 0,77 . This occurs due to the conversion of agricultural land that is less in favor of the agricultural side even though East Java is one of the areas that has the largest agricultural production. At the time of the covid-19, the performance of the agricultural sector in East Java Province is a non-base sector with an LQ value of 0,79. This happened because of the Covid-19 pandemic which affected food security due to an unsupportive situation and prone to production problems. The rise in value of LQ is expected to be better for agriculture sector performance. The factor that determines the performance of the agricultural sector is a factor of economic structure with a value of SSS greater than LSS.
\end{abstract}

Keywords: Agricultural Sector, Covid-19 Pandemic, Location Quotient, Shift Share

\section{PENDAHULUAN}

Pembangunan pertanian merupakan unsur utama dari proses pembangunan nasional. Pembangunan pertanian di Indonesia dianggap sebagai bagian penting dari pembangunan ekonomi, terutama saat sektor pertanian telah menjadi penyelamat perekonomian nasional karena pertumbuhannya positif, sedangkan sektor yang lain memiliki pertumbuhan negatif. Ada beberapa alasan mengapa pertanian Indonesia begitu penting: (1) potensi sumber dayanya sangat besar dan beragam, (2) kontribusinya terhadap pendapatan nasional cukup besar, dan (3) sebagian besar masyarakat menggantungkan mata pencahariannya pada sektor pertanian. (4) menjadi basis pertumbuhan di pedesaan (Sjamsir, 2017). Sektor pertanian merupakan sektor penunjang bagi sektor lainnya, yaitu sebagai penyedia input yang memengaruhi perkembangan ekonomi nasional.

Pembangunan ekonomi berorientasi dalam pembangunan ekonomi daerah otonom. Berdasarkan Undang-Undang No. 22 Tahun 1999 yang berganti menjadi Undang-Undang No. 32 Tahun 2004 tentang otonomi daerah, pembangunan ekonomi 
mengalami perubahan dari sentralis ke desentralisasi, yaitu memberi kebebasan kepada setiap daerah untuk mengembangkannya, juga dalam bidang ekonomi di dalamnya (Ristanti \& Handoyo, 2017). Jawa Timur termasuk salah satu wilayah yang memberlakukan sistem daerah otonom, yaitu daerah yang mempunyai batasan wilayah, daerah yang mempunyai kekuasaan untuk mengatur dan mengendalikan kegiatan pemerintahan dan kepentingan umum dalam satu kesatuan sistem Negara Kesatuan Republik Indonesia, menurut prakarsanya sendiri.

Provinsi Jawa Timur merupakan kontributor terbesar dalam perkembangan ekonomi nasional. Menurut data dari Badan Pusat Statistik (2021) Provinsi Jawa Timur memiliki urutan kedua dalam menopang perekonomian Indonesia setelah DKI Jakarta. Besarnya kontribusi Jawa Timur pada perekonomian nasional sebesar 14,57 persen pada tahun 2020. Pada tahun yang sama, Provinsi lain di Pulau Jawa yang memberikan kontribusi pada perekonomian nasional ada Provinsi DKI Jakarta sebesar 17,56 persen, Provinsi Jawa Barat sebesar 13,23 persen, Provinsi Jawa Tengah sebesar 8,54 persen, Provinsi Banten sebesar 3,97 persen, dan Provinsi DI Yogyakarta sebesar 0,88 persen. Perkembangan ekonomi di Pulau Jawa merupakan salah satu indikator perekonomian nasional, karena lebih dari separuh $(58,75 \%)$ pembangunan negara berasal dari Pulau Jawa.

Provinsi Jawa Timur adalah salah satu wilayah produksi pertanian terbesar di Indonesia. Sektor pertanian berkontribusi signifikan terhadap perekonomian Jawa Timur. Penopang perekonomian Jawa Timur salah satunya sektor pertanian. Menurut informasi dari Badan Pusat Statistik Provinsi Jawa Timur (2021), sektor pertanian pada tahun 2020 berada pada urutan ketiga dalam menyumbang perekonomian Jawa Timur, yakni 11,90 persen. Di mana sektor industri pengolahan berkontribusi paling besar dan selanjutnya diikuti sektor perdagangan besar dan eceran; reparasi mobil dan sepeda motor, memiliki nilai sebesar 30,69 persen dan 17,92 persen. Pada awal tahun 2020 muncul suatu wabah virus yaitu Coronavirus Disease 2019 atau yang biasa disebut Covid-19, mengakibatkan perubahan pola hidup di seluruh dunia. Virus ini berawal dari Kota Wuhan, Tiongkok yang kemudian menyebar di seluruh dunia, salah satunya Indonesia. Penyebaran virus Covid19 memberikan dampak bagi sejumlah sektor ekonomi yang ada di Indonesia, termasuk juga sektor pertanian. Menurut Tandibato et al. (2021) sejak awal wabah Covid-19, jalur perdagangan internasional terputus dan hampir setiap negara di dunia berusaha memenuhi kebutuhan pangannya. Saat ini, produksi dalam negeri adalah tujuan utama semua negara. Jika sektor pertanian tidak cukup bertahan dalam menghadapi wabah virus Covid-19 maka sektor pertanian akan terkena dampaknya. Menurut Dinas Pertanian dan Ketahanan Pangan Provinsi Jawa Timur (2020) setidaknya terdapat 6 dampak yang mungkin memengaruhi keberlangsungan kinerja sektor pertanian, yaitu belum meratanya distribusi; para petani menerima kelebihan pasokan yang menyebabkan harga lebih rendah; modal usaha terbatas selama musim tanam; keterbatasan pasar dalam mobilitas jam buka pasar, jam buka restoran, dan penutupan kantor; penurunan penghasilan dan penurunan daya beli petani; serta persoalan ketidakpastian distribusi saat semester I dan persoalan ketidakpastian produksi saat semester II. Menurut Yuana et al. (2020) sektor pertanian menjadi sesuatu yang menonjol dalam hal ketahanan pangan. Di tengah mewabahnya Covid-19, ketahanan pangan menjadi hal yang harus diperhatikan pemerintah agar tidak terjadi krisis pangan. Dalam situasi yang tidak menentu akibat Covid-19, sektor pertanian menjadi pengaman masyarakat Indonesia dalam memenuhi kebutuhan pangan. Berbagai hal seperti produksi pangan dan masalah pertanian belum terpantau dengan jelas di 
kondisi lapang, akan tetapi berbagai hasil analisis menunjukkan bahwa pengaruh wabah Covid-19 dapat menghambat proses suplai pangan dan melambungnya harga pangan di daerah-daerah. Kegiatan produksi pertanian dipengaruhi berbagai aspek. Menurut Putra \& Nasir (2015) dengan berkembangnya sektor lain, ketersediaan lahan pertanian sebagai salah satu input produksi semakin berkurang. Keadaan ini berdampak pada kelangkaan lahan. Selain ketersediaan lahan, peningkatan jumlah penduduk juga akan memberikan tekanan terhadap ketersediaan lahan di sektor pertanian. Hal ini disebabkan semakin meningkatnya jumlah penduduk terhadap ketersediaan lahan pertanian. Jumlah penduduk yang terus bertambah, dan kegiatan pembangunan yang dilakukan telah menyita fungsi lahan pertanian untuk menghasilkan pangan, dan menggantinya dengan penggunaan yang lain, seperti pemukiman, perkantoran, dan yang lainnya. Penelitian ini bertujuan untuk menganalisis posisi sektor pertanian di Provinsi Jawa Timur pada masa pandemi Covid-19 dengan menentukan posisi sektor pertanian pada saat sebelum pandemi Covid-19 dan saat terjadi pandemi Covid-19 serta mengidentifikasi faktor yang menentukan kinerja sektor pertanian.

\section{METODE PENELITIAN}

Penelitian ini dilaksanakan di Jawa Timur. Memilih Jawa Timur sebagai lokasi penelitian karena Provinsi Jawa Timur merupakan provinsi besar yang memberikan kontribusi perekonomian kedua setelah DKI Jakarta bagi perekonomian Indonesia serta sektor pertanian menjadi salah satu dari tiga sektor terbesar di antara sektor industri pengolahan dan sektor perdagangan yang berkontribusi dalam perekonomian Jawa Timur. Penelitian ini dikerjakan pada bulan Maret sampai Mei 2021.

Data yang diperlukan pada penelitian ini meliputi data PDRB (triwulan) Jawa Timur, PDB (triwulan) Indonesia, laju pertumbuhan (PDRB) Jawa Timur, dan laju pertumbuhan (PDB) Indonesia tahun 20192020. Pengumpulan data pada penelitian ini adalah data sekunder yang diperoleh dari Badan Pusat Statistik (BPS) dan Bank Indonesia (BI). Selain itu, data dan informasi yang didapat dari jurnal, artikel, internet, buku referensi, instansi-instansi terkait, serta kajian dari penelitian-penelitian terdahulu dapat mendukung demi kelengkapan penelitian ini.

Analisis data yang dipakai untuk membandingkan posisi sektor pertanian juga sektor non pertanian pada saat sebelum pandemi Covid-19 dan saat terjadi pandemi Covid-19 adalah analisis Location Quotient (LQ) dan untuk mengidentifikasi faktor penyebab kinerja sektor pertanian adalah analisis Shift Share. Analisis Location Quotient (LQ) adalah suatu alat analisis yang dapat menetapkan sektor perekonomian di suatu wilayah merupakan sektor basis atau sektor non basis dengan membandingkan peranannya dalam perekonomian Provinsi Jawa Timur atas peranan kegiatan sejenis dalam perekonomian nasional. Menurut Amalia (2012) teknik Location Quotient ini mengasumsikan bahwa semua masyarakat di suatu wilayah (regional) memiliki model permintaan yang serupa dengan model permintaan nasional, serta produk yang dihasilkan setiap sektor perekonomian adalah barang homogen. Menurut Ananda (2017) teori basis ekonomi mengidentifikasi perekonomian daerah menjadi 2 hal, yaitu kegiatan basis dan kegiatan bukan basis. Kegiatan basis adalah kegiatan yang mampu mengekspor produknya hingga di luar wilayah setempat. Kegiatan bukan basis adalah kegiatan yang hanya dapat memenuhi keperluan masyarakat yang tinggal di suatu wilayah dengan produk yang dihasilkan. Kegiatan produksi dan wilayah pasarnya hanya dalam skala lokal jadi kegiatan ini tidak mengekspor. Menurut Daryanto \& Hafizrianda (2010) indeks LQ (Location Quotient) dapat dijadikan parameter yang 
dapat menunjukkan ruang lingkup peran sektor di daerah. Sistematis perhitungan LQ dijabarkan sebagai berikut :

$$
\mathrm{LQ}=\frac{V \mathrm{i} / V_{\mathrm{t}}}{Y \mathrm{i} / Y_{\mathrm{t}}}
$$

Di mana :

LQ : Location Quotient

Vi : Nilai PDRB sektor (i) di wilayah Jawa Timur

Vt : Total PDRB di wilayah Jawa Timur

Yi : Nilai PDB sektor (i) di tingkat nasional

Yt : Total PDB di tingkat nasional dengan kriteria, apabila :

LQ > 1, sektor tersebut tergolong sektor basis yang menggerakkan daerah tersebut untuk melakukan ekspor produknya di luar batas daerah.

LQ < 1, sektor tersebut termasuk sektor non basis yang membutuhkan impor produk dari luar untuk pemenuhan masyarakat setempat.

$\mathrm{LQ}=1$, daerah tersebut bersifat tertutup karena minimnya transaksi di luar wilayah, namun situasi ini sulit ditemui dalam perekonomian daerah.

Analisis shift share merupakan analisis yang mampu mengidentifikasi faktor penyebab kinerja sektor pertanian. Menurut Syamsiyah \& Kurnia (2017) analisis shift share merupakan suatu alat analisis yang diterapkan untuk melihat kegiatan pertumbuhan ekonomi suatu wilayah. Menurut Mangilaleng et al. (2015) analisis shift share dapat melihat perubahan suatu sektor secara signifikan dengan sektor yang lain dan juga dapat menganalisis laju perekonomian dalam suatu wilayah. Menurut Suyatno (2000) analisis shift share terdiri dari dua unsur yaitu Structural Shift Share (SSS) dan Locational Shift Share (LSS), dengan rumus shift share sebagai berikut :

$$
\begin{aligned}
\text { TSS } & =\sum\left(g_{n}-g_{\text {in }}\right) X_{\text {ino }}+\sum\left(G_{i}-G\right) X_{\text {ino }}+ \\
& =\left(g_{\text {in }} G_{i}\right) X_{\text {ino }} \\
\text { SSS } & =\sum\left(g_{n}-g_{\text {in }}\right) X_{\text {ino }}+\sum\left(G_{i}-G\right) X_{\text {ino }} \\
\text { LSS } & =\sum\left(g_{\text {in }}-G_{i}\right) X_{\text {ino }}
\end{aligned}
$$

\begin{tabular}{|c|c|}
\hline$S$ & : Total Shift Share \\
\hline SSS & : Structural Shift Share \\
\hline , & : Locational Shift Share \\
\hline & $\begin{array}{l}\text { : Laju pertumbuhan (PDRB) } \\
\text { total sektor di Provinsi Jawa Timur }\end{array}$ \\
\hline & $\begin{array}{l}\text { : Laju pertumbuhan (PDRB) } \\
\text { sektor pertanian di Provinsi Jawa } \\
\text { Timur }\end{array}$ \\
\hline & $\begin{array}{l}\text { : Laju pertumbuhan (PDB) } \\
\text { sektor pertanian di Indonesia }\end{array}$ \\
\hline & $\begin{array}{l}\text { : Laju pertumbuhan (PDB) total } \\
\text { sektor di Indonesia }\end{array}$ \\
\hline & $\begin{array}{l}\text { PDRB sektor pertanian di } \\
\text { Provinsi Jawa Timur }\end{array}$ \\
\hline
\end{tabular}

Keterangan :

SSS > LSS maka faktor struktur ekonomi yang dominan dalam menentukan kinerja sektor pertanian.

SSS = LSS maka yang menentukan kinerja sektor pertanian adalah faktor struktur ekonomi dan faktor lokasi.
SSS < LSS maka faktor lokasi yang dominan dalam menentukan kinerja sektor pertanian.
(Novitasari et al., 2015)

\section{HASIL DAN PEMBAHASAN}

Pertumbuhan ekonomi adalah suatu proses transformasi perekonomian yang berlangsung di suatu wilayah selama periode waktu tertentu untuk keadaan ekonomi yang lebih baik. Jika kontribusi sektor ekonomi besar dan pertumbuhannya meningkat, maka akan memperlancar proses pertumbuhan ekonomi secara keseluruhan dan sebaliknya. Selama tahun 2017-2019, ekonomi Jawa Timur mengalami peningkatan sampai di angka 5 persen, yakni pada tahun 2017 pertumbuhan ekonomi Jawa Timur sebesar 
5,46 persen, dan terus mengalami peningkatan sebesar 5,52 persen pada tahun 2019. Akan tetapi, pada tahun 2020 ekonomi Jawa Timur terkontraksi sedalam 2,39 persen, mengalami kemerosotan dibanding periode sebelumnya. Hal ini dikarenakan sebagian besar lapangan usaha mengalami pertumbuhan negatif atau terkontraksi akibat pandemi Covid-19. Perekonomian tidak dapat diukur dengan besar kecilnya perekonomian itu sendiri, namun Covid-19 merupakan salah satu penyebab ketidakstabilan perekonomian baik secara nasional maupun global (Khairad, 2020).

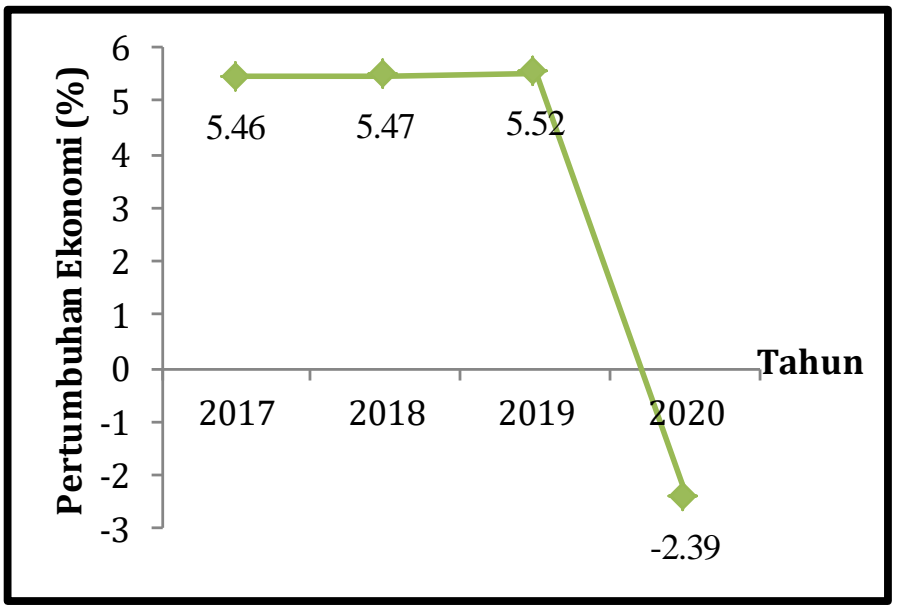

Sumber : BPS Provinsi Jawa Timur Tahun 2021

Gambar 1 Pertumbuhan Ekonomi Provinsi Jawa Timur, 2017-2020 (persen)

Pertumbuhan ekonomi Jawa Timur terjadi penurunan saat tahun 2020, namun sektor pertanian, kehutanan, dan perikanan cukup bertahan di masa pandemi Covid-19 dibuktikan dengan pertumbuhan sektor pertanian, kehutanan, dan perikanan yang bernilai positif dengan seiring menurunnya pertumbuhan lapangan usaha lainnya akibat pandemi Covid-19. Menurut Purba et al. (2020) sektor pertanian berpeluang besar untuk terus diandalkan dalam mengangkat perekonomian agar tidak mengalami masa resesi ekonomi terlalu dalam akibat pandemi Covid-19. Menurut Soleh (2014) pertumbuhan ekonomi menunjukkan tingkat kegiatan ekonomi yang menghasilkan pendapatan bagi masyarakat selama periode waktu tertentu. Dengan kata lain, apabila dalam satu tahun pendapatan masyarakat lebih besar dari pendapatan tahun sebelumnya, maka kondisi seperti ini dapat dikatakan perekonomian mengalami pertumbuhan.

Tabel 1 Laju Pertumbuhan PDRB Menurut Lapangan Usaha, 2017-2020 (persen)

\begin{tabular}{llrrrr}
\hline & \multicolumn{1}{c}{ Lapangan Usaha } & 2017 & 2018 & 2019 & 2020 \\
\hline A & Pertanian, Kehutanan, dan Perikanan & 1,58 & $-2,13$ & 1,18 & 0,94 \\
B & Pertambangan dan Penggalian & 7,48 & 2,40 & 1,47 & $-4,18$ \\
C & Industri Pengolahan & 5,69 & 7,55 & 6,85 & $-2,06$ \\
D & Pengadaan Listrik dan Gas & 2,58 & $-2,19$ & 1,38 & $-2,39$ \\
E & Pengadaan Air, Pengelolaan Sampah, & 6,44 & 4,18 & 4,71 & 5,03 \\
& Limbah dan Daur Ulang & 6,91 & 6,61 & 5,89 & $-3,28$ \\
F & Konstruksi & & & & \\
& & & &
\end{tabular}




\begin{tabular}{|c|c|c|c|c|c|}
\hline G & $\begin{array}{l}\text { Perdagangan Besar dan Eceran; } \\
\text { Reparasi Mobil dan Sepeda Motor }\end{array}$ & 6,26 & 6,19 & 5,96 & $-5,74$ \\
\hline $\mathrm{H}$ & Transportasi dan Pergudangan & 6,62 & 6,56 & 3,77 & $-11,16$ \\
\hline I & $\begin{array}{l}\text { Penyediaan Akomodasi dan Makan } \\
\text { Minum }\end{array}$ & 7,91 & 7,62 & 7,55 & $-8,87$ \\
\hline $\mathrm{J}$ & Informasi dan Komunikasi & 6,92 & 6,75 & 7,36 & 9,83 \\
\hline $\mathrm{K}$ & Jasa Keuangan dan Asuransi & 2,44 & 4,72 & 3,80 & 0,18 \\
\hline $\mathrm{L}$ & RealEstat & 3,91 & 6,24 & 6,03 & 3,95 \\
\hline $\mathrm{M}, \mathrm{N}$ & Jasa Perusahaan & 5,53 & 7,15 & 6,66 & $-7,22$ \\
\hline $\mathrm{O}$ & $\begin{array}{l}\text { Administrasi Pemerintahan, } \\
\text { Pertahanan dan Jaminan Sosial Wajib }\end{array}$ & 2,22 & 4,20 & 3,72 & $-0,39$ \\
\hline $\mathrm{P}$ & Jasa Pendidikan & 3,99 & 5,41 & 7,27 & 3,96 \\
\hline Q & Jasa Kesehatan dan Kegiatan Sosial & 5,39 & 7,61 & 7,55 & 8,70 \\
\hline $\mathrm{R}, \mathrm{S}, \mathrm{T}, \mathrm{U}$ & Jasa lainnya & 4,46 & 4,98 & 6,26 & $-13,80$ \\
\hline Produk & omestik Regional Bruto & 5,46 & 5,47 & 5,52 & $-2,39$ \\
\hline
\end{tabular}

Sumber : BPS Provinsi Jawa Timur Tahun 2021

Perkembangan ekonomi Indonesia melambat selama pandemi Covid-19 pada kuartal pertama dan kedua, dan kebijakan pemerintah untuk mencegah penyebaran Covid-19 telah memperlambat laju pertumbuhan ekonomi dan masyarakat dengan berkurangnya pendapatan. Dengan diberlakukannya penerapan protokol kesehatan, (PSBB) Pembatasan Sosial Berskala Besar, dan Learn/Work From Home (LFH/WFH), masyarakat harus tetap di rumah dan mengurangi aktivitas luar ruangan yang tidak penting (Ulya, 2021). Sebagian besar pertumbuhan ekonomi Jawa Timur bernilai negatif akibat terkena dampak dari pandemi Covid-19, tetapi ada pula yang tumbuh bernilai positif (mampu bertahan) akibat pandemi Covid-19 melanda, salah satunya sektor pertanian, kehutanan, dan perikanan yang memiliki pertumbuhan positif sebesar 0,94 persen. Kebutuhan pangan merupakan hal yang harus dipenuhi oleh seluruh masyarakat sehingga kegiatan produksi pertanian harus tetap berjalan pada saat Covid-19 ini mewabah. Sektor pertanian pada masa pandemi Covid-19 dapat dijadikan peluang bagi petani untuk meningkatkan kesejahteraannya seiring konsumen mulai mencari pangan dan hasil pertanian untuk memenuhi kebutuhannya.
Misalnya, perilaku panic buying dapat menyebabkan pasokan pangan menjadi terbatas, sehingga harga pangan menjadi naik di tengah wabah Covid-19.

\section{Analisis Kinerja Sektor Pertanian dan Sektor Non Pertanian Sebelum Pandemi Covid-19}

Analisis yang dipakai untuk menentukan kinerja sektor pertanian dan sektor non pertanian sebelum pandemi Covid-19 adalah analisis LQ. Analisis LQ dipilih karena dapat menetapkan posisi sektor pertanian dan sektor non pertanian di Provinsi Jawa Timur tergolong sektor basis atau sektor non basis dengan membandingkan nilai PDRB Provinsi Jawa Timur dengan PDB di tingkat nasional. Menurut Negara \& Putri (2020) sektor basis dan sektor non basis merupakan bagian dari teori basis ekonomi, yakni kegiatan ekonomi yang memanfaatkan potensi lokal, seperti sumber daya manusia dan bahan baku demi menciptakan kekayaan dan lapangan kerja di wilayah tersebut. Pertumbuhan wilayah dikatakan efektif apabila kegiatan ekonominya menciptakan arus hingga di luar batas wilayah, seperti kegiatan mengekspor.

Data yang digunakan adalah data PDRB triwulan ADHK 2010 dan PDB triwulan ADHK 2010 meliputi data triwulan 
I-2019, triwulan II-2019, triwulan III-2019, triwulan IV-2019, dan triwulan I-2020. Hasil perhitungan LQ dalam menetapkan posisi sektor pertanian dan sektor non pertanian sebelum pandemi Covid-19 disajikan pada tabel 2.

Tabel 2 Analisis LQ Sebelum Pandemi Covid-19

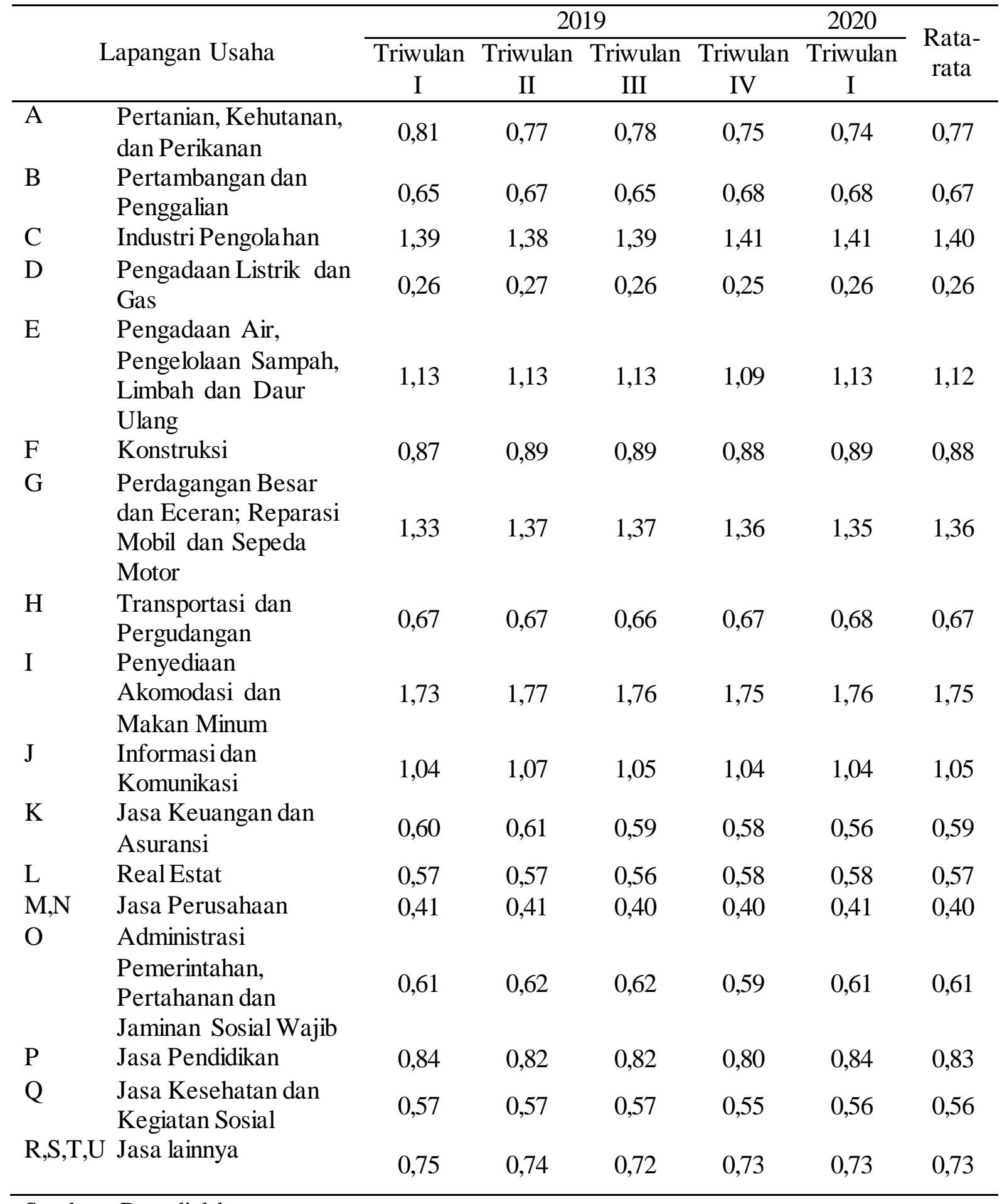

Sumber : Data diolah 
Berdasarkan analisis LQ yang ditunjukkan dalam tabel 2, sektor perekonomian di Jawa Timur yang memiliki nilai LQ > 1, yakni tergolong sektor basis ada lima, yaitu sektor pengadaan air, pengelolaan sampah, limbah dan daur ulang; sektor industri pengolahan; sektor penyediaan akomodasi dan makan minum; sektor perdagangan besar dan eceran; reparasi mobil dan sepeda motor; serta sektor informasi dan komunikasi. Sebaliknya, sektor perekonomian di Jawa Timur yang merupakan sektor non basis (LQ $<1$ ) ada dua belas, yaitu sektor pertanian, kehutanan, dan perikanan; sektor pengadaan listrik dan gas; sektor pertambangan dan penggalian; sektor konstruksi; sektor jasa keuangan dan asuransi; sektor transportasi dan pergudangan; sektor real estat; sektor administrasi pemerintahan, pertahanan dan jaminan sosial wajib; sektor jasa perusahaan; sektor jasa lainnya; sektor jasa kesehatan dan kegiatan sosial; serta sektor jasa pendidikan.

Sektor perekonomian yang memiliki nilai LQ tertinggi di Provinsi Jawa Timur adalah sektor penyediaan akomodasi dan makan minum. Tingginya nilai LQ sejalan dengan tingginya laju pertumbuhan sektor penyediaan akomodasi dan makan minum, yaitu sebesar 7,55 persen. Keadaan pariwisata di Provinsi Jawa Timur semakin berkembang diiringi munculnya objek-objek wisata yang baru serta pengembangan potensi wisata dengan menyuguhkan konsep yang menarik. Hal ini dapat menarik perhatian wisatawan untuk mengunjungi kawasan tersebut. Selain keindahan objek wisata yang disuguhkan, perlu memperhatikan kebutuhan wisatawan, seperti kebutuhan konsumsi, jasa, dan produksi industri pariwisata. Contoh kawasan di Jawa Timur yang potensinya dikembangkan menjadi kawasan wisata, yakni Desa Tamansari, Banyuwangi; Kampung Coklat, Blitar; Desa Pujon Kidul,
Malang; dll. Munculnya suatu kawasan wisata dapat memberikan manfaat bagi lingkungan sekitar pula, dengan mendirikan tempat makan, toilet, penginapan, dan sebagainya. Dengan begitu bidang pariwisata dapat menciptakan serta meningkatkan lapangan kerja yang dapat menopang pertumbuhan ekonomi Provinsi Jawa Timur.

Sektor pertanian, kehutanan, dan perikanan pada saat sebelum terjadinya pandemi Covid-19 termasuk sektor non basis. Ditandai oleh nilai ratarata analisis LQ sebesar 0,77 yang artinya nilai LQ $<1$. Untuk pemenuhan kebutuhan masyarakat Jawa Timur masih memerlukan impor dari luar. Hal ini disebabkan oleh penurunan produksi pertanian akibat pengalihan fungsi lahan pertanian menjadi lahan non pertanian. Menurunnya produksi pertanian diikuti oleh berkurangnya jumlah lahan pertanian.

\section{Analisis Kinerja Sektor Pertanian dan Sektor Non Pertanian Saat Terjadi Pandemi Covid-19}

Analisis yang dipakai untuk menetapkan kinerja sektor pertanian dan sektor non pertanian saat terjadi pandemi Covid-19 adalah analisis LQ. Analisis LQ yaitu suatu indikator yang yang dapat menunjukkan posisi sektor pertanian dan sektor non pertanian tergolong sektor basis atau sektor non basis dengan membandingkan peranan sektor perekonomian di Provinsi Jawa Timur atas sektor perekonomian sejenis di tingkat nasional. Menurut Jumiyanti (2018) analisis LQ diterapkan untuk mengkaji kondisi ekonomi yang berorientasi pada penetapan kegiatan ekonomi tertentu untuk mendapatkan perkiraan sektor unggulan sebagai leading sector.

Data yang digunakan dalam menganalisis sektor pertanian dan sektor non pertanian saat pandemi Covid-19 melanda adalah data PDRB triwulan ADHK 2010 dan PDB triwulan ADHK 2010 melipui data triwulan II-2020, triwulan III-2020, dan 
triwulan IV-2020. Hasil perhitungan LQ dapat dilihat dalam tabel 3.

Tabel 3 Analisis LQ Saat Terjadi Pandemi Covid-19

\begin{tabular}{|c|c|c|c|c|c|}
\hline & \multirow[b]{2}{*}{ Lapangan Usaha } & \multicolumn{3}{|c|}{2020} & \multirow[b]{2}{*}{ Rata-rata } \\
\hline & & $\begin{array}{l}\text { Triwulan } \\
\text { II }\end{array}$ & $\begin{array}{l}\text { Triwulan } \\
\text { III }\end{array}$ & $\begin{array}{l}\text { Triwulan } \\
\text { IV }\end{array}$ & \\
\hline $\mathrm{A}$ & $\begin{array}{l}\text { Pertanian, Kehutanan, } \\
\text { dan Perikanan }\end{array}$ & 0,82 & 0,81 & 0,74 & 0,79 \\
\hline $\mathrm{B}$ & $\begin{array}{l}\text { Pertambangan dan } \\
\text { Penggalian }\end{array}$ & 0,62 & 0,61 & 0,69 & 0,64 \\
\hline $\mathrm{C}$ & Industri Pengola han & 1,40 & 1,42 & 1,44 & 1,42 \\
\hline $\mathrm{D}$ & $\begin{array}{l}\text { Pengadaan Listrik dan } \\
\text { Gas }\end{array}$ & 0,27 & 0,26 & 0,26 & 0,26 \\
\hline $\mathrm{E}$ & $\begin{array}{l}\text { Pengadaan Air, } \\
\text { Pengelolaan Sampah, } \\
\text { Limbah dan Daur } \\
\text { Ulang }\end{array}$ & 1,14 & 1,14 & 1,11 & 1,13 \\
\hline $\mathrm{F}$ & Konstruksi & 0,90 & 0,92 & 0,85 & 0,89 \\
\hline G & $\begin{array}{l}\text { Perdagangan Besar } \\
\text { dan Eceran; Reparasi } \\
\text { Mobil dan Sepeda } \\
\text { Motor }\end{array}$ & 1,31 & 1,32 & 1,37 & 1,34 \\
\hline $\mathrm{H}$ & $\begin{array}{l}\text { Transportasi dan } \\
\text { Pergudangan }\end{array}$ & 0,71 & 0,68 & 0,73 & 0,71 \\
\hline I & $\begin{array}{l}\text { Penyediaan } \\
\text { Akomodasi dan } \\
\text { Makan Minum }\end{array}$ & 1,87 & 1,77 & 1,78 & 1,81 \\
\hline $\mathrm{J}$ & $\begin{array}{l}\text { Informasi dan } \\
\text { Komunikasi }\end{array}$ & 1,08 & 1,04 & 1,04 & 1,05 \\
\hline $\mathrm{K}$ & $\begin{array}{l}\text { Jasa Keuangan dan } \\
\text { Asuransi }\end{array}$ & 0,60 & 0,60 & 0,57 & 0,59 \\
\hline $\mathrm{L}$ & Real Estat & 0,59 & 0,58 & 0,59 & 0,59 \\
\hline $\begin{array}{l}\mathrm{M}, \mathrm{N} \\
\mathrm{O}\end{array}$ & $\begin{array}{l}\text { Jasa Perusahaan } \\
\text { Administrasi }\end{array}$ & 0,41 & 0,39 & 0,39 & 0,40 \\
\hline & $\begin{array}{l}\text { Pemerintahan, } \\
\text { Pertahanan dan } \\
\text { Jaminan Sosial Wajib }\end{array}$ & 0,64 & 0,62 & 0,58 & 0,61 \\
\hline $\mathrm{P}$ & Jasa Pendidikan & 0,85 & 0,84 & 0,82 & 0,84 \\
\hline Q & $\begin{array}{l}\text { Jasa Kesehatan dan } \\
\text { Kegiatan Sosial }\end{array}$ & 0,60 & 0,54 & 0,51 & 0,55 \\
\hline $\mathrm{R}, \mathrm{S}, \mathrm{T}, \mathrm{U}$ & Jasa lainnya & 0,56 & 0,65 & 0,70 & 0,64 \\
\hline
\end{tabular}

Sumber : Data diolah

Tabel 3 menunjukkan bahwa berdasarkan analisis LQ, kondisi sektor perekonomian pada saat terjadi pandemi Covid-19 yang tergolong sektor basis (LQ > 1) adalah sektor pengadaan air, pengelolaan sampah, limbah dan daur ulang; sektor industri pengolahan; sektor penyediaan akomodasi dan makan minum; sektor perdagangan besar dan eceran; reparasi mobil dan sepeda 
motor; dan sektor informasi dan komunikasi. Selain sektor perekonomian yang disebutkan sebelumnya merupakan sektor non basis karena nilai location quotient kurang dari 1. Sektor perekonomian berdasarkan tabel 3 yang bukan sektor basis adalah sektor konstruksi; sektor jasa perusahaan; sektor pertanian, kehutanan, dan perikanan; sektor administrasi pemerintahan, pertahanan dan jaminan sosial wajib; sektor pengadaan listrik dan gas; sektor jasa keuangan dan asuransi; sektor pertambangan dan penggalian; sektor jasa kesehatan dan kegiatan sosial; sektor real estat; sektor jasa pendidikan; sektor transportasi dan pergudangan; dan sektor jasa lainnya.

Berdasarkan tabel 3, nilai LQ tertinggi sebesar 1,81 dimiliki oleh sektor penyediaan akomodasi dan makan minum di Provinsi Jawa Timur pada saat pandemi Covid-19. Sektor penyediaan akomodasi dan makan minum termasuk salah satu sektor yang terkena imbas pandemi Covid-19. Sejumlah pariwisata terjadi penurunan dalam semua aspek, dengan pertumbuhan ekonominya sebesar $-8,87 \%$. Walaupun pertumbuhan ekonominya terkontraksi tetapi sektor penyediaan akomodasi dan makan minum masih menjadi sektor basis. Penyesuaian operasional bidang pariwisata dengan kebijakan normal baru dapat membantu memulihkan kinerja sektor pariwisata. Contohnya sektor pariwisata banyuwangi yang membuat empat penyesuaian dalam merubah mindset pelaku pariwisata yang dapat menarik minat wisatawan pada masa pandemi Covid-19. Empat aspek tersebut meliputi : (1) akomodasi dengan memperhatikan Cleanness, Healthy, \& Safety (CHS); (2) atraksi wisata yang mempertimbangkan kapasitas pengunjung (pembatasan pengunjung); (3) preferensi wisatawan dengan mendorong aktivitas wisata yang bersifat outdoor, private tour, serta wisata kesehatan; dan (4) pengaturan jam buka wisata dengan aturan enam hari dalam seminggu mulai pukul 8 pagi hari sampai pukul 4 sore hari. Hal ini dapat dilakukan di masa pandemi seperti ini untuk membantu aktivitas pelaku pariwisata dengan tetap menerapkan protokol kesehatan.

Sektor pertanian, kehutanan, dan perikanan mempunyai nilai LQ sebesar 0,79 yang artinya sektor pertanian pada saat terjadi Covid-19 merupakan sektor non basis. Hal ini dikarenakan nilai location quotient kurang dari 1. Kondisi pandemi Covid-19 mempengaruhi ketahanan pangan di Indonesia karena situasi yang tidak mendukung serta rentan terjadi masalah produksi. Kondisi pandemi Covid-19 mengakibatkan ketersediaan pangan dipersulit dengan memburuknya pandemi itu sendiri dan akibat pembatasan ruang gerak (Sudarmansyah et al., 2021). Saat Covid-19 mewabah daerah Jawa Timur, pemerintah menetapkan kebijakan Pembatasan Sosial Berskala Besar (PSBB), yang artinya segala bentuk kegiatan dibatasi ruang geraknya, kebijakan tersebut diupayakan guna menghambat penyebaran virus Covid-19. Kebijakan ini berdampak pada terhalangnya distribusi produk pertanian sampai ke pasar tujuan. Contohnya petani yang biasa memasok kebutuhan pangan ke hotel, restoran, dan katering menerima pembatalan pesanan karena berhentinya aktivitas dalam sementara waktu. Hal ini sejalan dengan penelitian Ikhsanti (2020) bahwa sejak diberlakukannya PSBB sektor pertanian mengalami kesulitan dalam mendistribusikan hasil pertaniannya.

\section{Faktor yang Menentukan Kinerja Sektor Pertanian}

Analisis yang digunakan dalam menentukan faktor penyebab kinerja sektor pertanian di Provinsi Jawa Timur menggunakan analisis Shift Share, yaitu persamaan Total Shift Share (TSS) yang terdiri dari dua bagian, di antaranya Structural Shift Share (SSS) dan Locational Shift Share (LSS). Menurut Basuki \& Mujiraharjo (2017) analisis Shift 
Share dapat digunakan sebagai teknik yang dapat mengetahui transformasi struktur ekonomi daerah terhadap perekonomian nasional. Data yang digunakan dalam mengidentifikasi faktor apa yang menentukan kinerja sektor pertanian adalah data laju pertumbuhan (PDRB) Provinsi Jawa Timur dan laju pertumbuhan (PDB) Indonesia tahun 2019-2020. Hasil perhitungan analisis Shift Share tertera dalam tabel 4.

Tabel 4 Hasil Perhitungan Shift Share Pada Sektor Pertanian, Kehutanan, dan Perikanan

\begin{tabular}{cccc}
\hline \multicolumn{1}{c}{ Lapangan Usaha } & SSS & LSS & Faktor Penentu \\
\hline $\begin{array}{l}\text { Pertanian, Kehutanan, } \\
\text { dan Perikanan }\end{array}$ & 495557,218 & $-538259,823$ & Struktur ekonomi \\
\hline
\end{tabular}

Sumber : Data diolah

Tabel 4 menandakan bahwa berdasarkan analisis shift share, faktor yang memengaruhi kinerja sektor pertanian, kehutanan, dan perikanan adalah struktur ekonominya karena nilai SSS lebih besar dari pada LSS. Hal ini berkaitan dengan berkurangnya fungsi lahan pertanian akibat konversi lahan pertanian menjadi lahan non pertanian. Pengalihan fungsi lahan ini berdampak pada menurunnya jumlah produksi. Selain pengalihan fungsi lahan pertanian, kejadian tak terduga selama masa bertani juga dapat mempengaruhi kinerja sektor pertanian, kehutanan, dan perikanan, seperti terserang hama dan penyakit, kondisi iklim dan bencana alam, hingga harga jual yang anjlok.

\section{KESIMPULAN}

Hasil penelitian ini dapat disimpulkan bahwa :

1. Nilai LQ sektor pertanian di Provinsi Jawa Timur pada saat sebelum pandemi Covid-19 adalah 0,77 yang menandakan bahwa sektor pertanian tergolong sektor non basis saat Covid-19 mewabah. Hal ini terjadi akibat alih fungsi lahan pertanian yang kurang memihak sisi pertanian padahal Jawa Timur termasuk salah satu wilayah yang memiliki produksi pertanian terbesar.

2. Nilai LQ sektor pertanian di Provinsi Jawa Timur saat terjadi pandemi Covid19 adalah 0,79 yang menandakan bahwa sektor pertanian tergolong sektor non basis saat Covid-19 mewabah. Hal ini terjadi karena kondisi pandemi Covid-19 yang memengaruhi ketahanan pangan karena situasi yang tidak mendukung serta rentan terjadi masalah produksi.

3. Faktor yang memengaruhi kinerja sektor pertanian di Provinsi Jawa Timur adalah struktur ekonomi dengan nilai SSS lebih besar daripada LSS.

\section{DAFTAR PUSTAKA}

Amalia, F. (2012). Penentuan Sektor Unggulan Perekonomian Wilayah Kabupaten Bone Bolango dengan Pendekatan Sektor Pembentuk PDRB. Jurnal Etikonomi, 11(2), 196-207.

Ananda, C. F. (2017). Pembangunan Ekonomi Daerah: Dinamika dan Strategi Pembangunan. UB Press.

Badan Pusat Statistik Provinsi Jawa Timur. (2021). Produk Domestik Regional Bruto Provinsi Jawa Timur Menurut Lapangan Usaha 2016-2020.

Basuki, M., \& Mujiraharjo, F. N. (2017). Analisis Sektor Unggulan Kabupaten Sleman dengan Metode Shift Share dan Location Quotient. Jurnal Sains, Teknologi Dan Industri, 15(1), 52-60.

Daryanto, A., \& Hafizrianda, Y. (2010). Model-Model Kuantitatif untuk 
Perencanaan Pembangunan Ekonomi

Daerah: Konsep dan Aplikasi. PT Penerbit IPB Press.

Ikhsanti, N. (2020). Strategi Perencanaan Ekonomi dalam Mengatasi Dampak Pandemi Covid-19 di Sumatra Barat. Jurnal Ekonomi Keuangan Dan Perencanaan Indonesia, 1(1), 11-21.

Jumiyanti, K. R. (2018). Analisis Location Quotient dalam Penentuan Sektor Basis dan Non Basis di Kabupaten Gorontalo. Gorontalo Development Review, 1(1), 29.

Khairad, F. (2020). Sektor Pertanian di Tengah Pandemi COVID-19 Ditinjau dari Aspek Agribisnis. Jurnal Agriuma, 2(2), 82-89.

Mangilaleng, E. J., Rotinsulu, D., \& Rompas, W. (2015). Analisis Sektor Unggulan Kabupaten Minahasa Selatan. Jurnal Berkala Ilmiah Efisiensi, 15(04), 193-205.

Negara, A. K. K., \& Putri, A. K. (2020). Analisis Sektor Unggulan Kecamatan Toboali dengan Metode Shift Share dan Location Quotient. Jurnal Ekonomi, 8(1), 24-36.

Novitasari, R., Herdiansah, D., \& Pardani, C. (2015). Analisis Kinerja Sektor Pertanian dalam Perekonomian Wilayah di Kota Banjar. Jurnal Ilmiah Mahasiswa AGROINFO GALUH, 2(1), 41-48.

Purba, H. J., Yusuf, E. S., \& Erwidodo. (2020). Dampak Pandemi Covid-19 Terhadap Pertumbuhan Ekonomi dan Sektor Pertanian. Pusat Sosial Ekonomi Dan Kebijakan Pertanian, 23-46.

Putra, H., \& Nasir, M. (2015). Analisis Faktor-Faktor Yang Mempengaruhi Produksi Sektor Pertanian Di Propinsi
Aceh. Jurnal Agrisep, 16(1), 53-60.

Ristanti, Y. D., \& Handoyo, E. (2017). Undang-Undang Otonomi Daerah dan Pembangunan Ekonomi Daerah. Jurnal Riset Akutansi Keuangan, 2(2), 115122.

Sjamsir, Z. (2017). Pembangunan Pertanian dalam Pusaran Kearifan Lokal (P. Rappana (ed.)). CV Sah Media.

Soleh, A. (2014). Pertumbuhan Ekonomi dan Kemiskinan di Indonesia. EKOMBIS REVIEW: Jurnal Ilmiah Ekonomi Dan Bisnis, 197-209.

Sudarmansyah, Ruswendi, Ishak, A., Fauzi, E., Yuliasari, S., \& Firison, J. (2021). Peran Penyuluh Pertanian dalam Mendukung Ketahanan Pangan Pada Saat Wabah Pandemi Covid-19. Jurnal AGRIBIS, 14(1).

Suyatno. (2000). Analisa Economic Base Terhadap Pertumbuhan Ekonomi Daerah Tingkat II Wonogiri : Menghadapi Implementasi UU No. 22/1999 dan UU No. 5/1999. Jurnal Ekonomi Pembangunan, 1(2), 144-159.

Syamsiyah, N., \& Kurnia, G. (2017). Analisis Struktur Perekonomian Berdasarkan Pendekatan Shift Share dalam Pengembangan Agrowisata di Kabupaten Cirebon. Jurnal Agribisnis Terpadu, 10(2), 201-211.

Tandibato, H. E., Kaunang, R., \& Memah, M. Y. (2021). Kinerja Penyuluh Pertanian dalam Masa Pandemi Covid19 di Kelurahan Taratara Satu Kecamatan Tomohon Barat Kota Tomohon. Agri-Sosioekonomi, 17(2), 251-260.

Timur, D. P. dan K. P. P. J. (2020). Kebijakan Pertanian Terkait Penanganan Pandemi Covid-19 Bagi 
Pelaku Sektor Pertanian. Universitas Jember.

Ulya, H. N. (2021). Pemulihan Perekonomian Jawa Timur di Masa Pandemi Covid-19 Melalui Sistem Pertanian Terpadu (SPT) Budikdamber (Budidaya Ikan dalam Ember). JoIE:
Journal of Islamic Economics, 1(1), 41-66.

Yuana, A. S., Kholifah, S., \& Anas, M. (2020). Mekanisme Survival Petani "Gurem" pada Masa Pandemi. Jurnal Sosiologi Walisongo, 4(2), 201-214. 